\title{
Government Mass Mobilization of Districts in Ho Chi Minh City
}

\section{Ngoc Loi Pham}

Ho Chi Minh City Cadre Academy, Ho Chi Minh City, Vietnam

\author{
Email address: \\ phamngocloi728@gmail.com
}

\section{To cite this article:}

Ngoc Loi Pham. Government Mass Mobilization of Districts in Ho Chi Minh City. International Journal of Philosophy.

Vol. 9, No. 2, 2021, pp. 111-115. doi: 10.11648/j.ijp.20210902.16

Received: May 14, 2021; Accepted: June 7, 2021; Published: June 15, 2021

\begin{abstract}
Deep awareness of government mass mobilization is necessary to work. On September 21, 2000, the Prime Minister issued Directive No. 18/2000 / CT-TTg on "Strengthening mass mobilization work". In this study, the author aims to explore the theories as well as practical issues about mass mobilization of districts in Ho Chi Minh City. The author proposes two hypotheses: First, the mobilization work of district authorities is the activities of institutions, cadres, and civil servants in the district government system to implement the policy, resolutions, and directives of the Party, laws of the State on mobilization work. Propagating, mobilizing, and organizing all the people in the district, related institutions, and forces to form a great force and power of the entire people to successfully implement the Party's guidelines, policies, and laws of the State. Second, the issues arise in the mobilization of the authorities of the districts in Ho Chi Minh City today. The author has used research methods including analysis and synthesis, interpretation and induction, abstraction and generalization, logic, history, comparison to come to conclusions about theoretical and practical issues of mass mobilization of the districts in Ho Chi Minh City.
\end{abstract}

Keywords: Government Mass Mobilization, Districts, Ho Chi Minh City

\section{Introduction}

In all times, especially when the Communist Party of Vietnam is in power, mass mobilization in general and government mass mobilization play a crucial part in the victory of the revolutions. In the article "Mass mobilization" (Dan Van) written in 1949, President Ho Chi Minh stated, "The force of the people is very powerful. Mass mobilization is important. Poor mass mobilization leads to poor performance of every work. Good mass mobilization leads to the success of every work". President Ho Chi Minh highly appreciated and placed the top priority on the role of government mass mobilization when the ruling party is in power.

In the current renewal process, our entire Party, people, and armed forces are making every effort to successfully implement the goals and tasks of the renovation; to build a socialist-oriented market economy; to promote industrialization and modernization of the country; to build a rule of law state of the people, by the people and for the people. It is an enormous, heavy, and new task created in favorable conditions, but it is also facing many difficulties and challenges. The hostile forces are intensifying to destroy our people's renewal cause under the leadership of the Party and the management of our State. This reality requires strengthening the leadership and renewing mass mobilization in general and government mass mobilization at all levels in particular, to mobilize the people to successfully realize those goals and tasks.

In the process of development and integration, Ho Chi Minh City has always been an economic, financial, commercial, and service center of the country, of the southern economic region, and one of the three country's largest economic regions. Besides the advantages and progress mentioned above, the city still has many shortcomings, including the mobilization work of the districts. Many government officials, including some leading officials and managers, have not been fully and deeply aware of the mass mobilization work of the government in general, of the district government in particular. Some districts still show signs of disregard for and do not care about government mass mobilization. The contents and methods of 
mass mobilization of the district government are less attractive and have not been strongly reformed. With the position of Ho Chi Minh City in the current period, the requirements of the reform goals and tasks in the districts, the requirement of building a Vietnam socialist rule-of-law state of the people, by the people and for the people; building an urban government, improving the position and role of the city government in general, district authorities in particular; promoting the advantages, overcoming the limitations and weaknesses of the mass mobilization work mentioned above, it is necessary to study in a basic and systematic way to find solutions to strengthen government mass mobilization in the districts of Ho Chi Minh City in the coming years - a critical and urgent issue.

\section{Literature Review}

\subsection{The Origins of Government Mass Mobilization}

Studying Marxism-Leninism in this field, we find that $\mathrm{K}$. Marx, F. Engels, and V. I. Lenin all showed that the Communist parties must mobilize people. It is a long-term job and needs persistent implementation. The working class had to campaign for the support of the majority of the people in its revolutionary struggle. Each different era of revolution must have different forms and contents of mobilization work.

Studying the history of class struggle since 1848, especially the Paris Commune and the workers' struggle for socialism in the late nineteenth century, in the work "The struggle of the residential class France from 1848 to 1850 " K. Marx stated that the Communist Party must know to persuade, enlighten and gather a large number of people, train the masses to dare to devote themselves to the struggle to win the victory [1].

V. I. Lenin applied the thought of C. Marx and F. Engels in his time - the era of imperialism and proletarian revolution and called for the expansion of the solidarity of the working class with the oppressed peoples around the world, which expanded the great bloc of unity contributed to victory in the revolution of October 1917. In building socialism, He emphasized the mobilization and promotion of all forces of the masses.

Applying and developing views of K. Marx, F. Engels, V. I. Lenin, Ho Chi Minh affirmed: "Revolution must first enlighten people" [2]. To enlighten the people, "first of all, there must be a destiny Party to mobilize and organize the people inside, to contact the oppressed people and the proletariat everywhere" [3].

In 1949, Ho Chi Minh pointed out that: All-Party cadres and organizations, authorities, and people's unions must do the work of mobilization according to their methods suitable to each organization: "Government officials and the local mass organizations must work together carefully, share the work clearly, then together explain to the people, encourage the people, help the people plan, organize the workers, and arrange the work. do, encourage, urge, track, help gradually solve difficult things... " [4]. Ho Chi Minh has selectively absorbed the traditional ideas of the nation and applied creatively Marxist-Leninist views on the masses of the people and mobilization work into our country's circumstances. It is the ideological basis and point of view to direct the Party's mass mobilization work in the national revolution, the people's democracy, the socialist revolution.

\subsection{Concepts and Theoretical Framework}

Mass mobilization is defined as a process that engages and motivates a wide range of partners and allies at national and local levels to raise awareness of and demand for a particular development objective through face-to-face dialogue [4] Mass mobilization work is the action of the government at all levels to mobilize the people to implement guidelines of the Party and the laws of the State, government officials, mass organizations and all members of people's organizations must be in charge of mass mobilization" [5]. From the early years of the renovation, the Communist Party of Vietnam also affirmed: "Mass mobilization work is the responsibility of the Party, the State and the mass organizations" [6]. Mass mobilization work is necessary to the Party, State, and mass organizations in implementing the way to socialism in our country. The late General Secretary Nguyen Van Linh said that it was necessary to strengthen the mobilization of the masses to consolidate the strength of national solidarity and social consensus to create fundamental changes in the comprehensive renewal of the country. He indicated the essential role of mass mobilization in the cause of the Vietnamese revolution. "Mass mobilization in each revolutionary period is of decisive significance". Mobilization, propaganda, and education of the masses to understand their real ownership role is an essential issue of mass mobilization work in the Vietnamese revolution. Activities of mass mobilization work must grasp the principle of "taking people as the base". Government officials, branches, and levels must attach great importance to mass mobilization, considering this work as a vital factor in all revolutionary activities [7-9]. In his works, Huy Tho has recorded the entire transformation context in which the Party, the State, and mass organizations focused on bringing the Party's guidelines and policies into life. The most crucial issue is to identify specific models and policies to implement comprehensive mass mobilization work [10].

During the period of accelerating industrialization and modernization of the country and international integration, the Party's view on the concept of the government's mass mobilization work has not changed. The book titled "Mass mobilization work of the Party in the period of accelerating industrialization and modernization of the country compiled by the Central Commission for Mobilization has contributed to researching and clarifying several theoretical and practical issues of mass mobilization. It affirms that revolution is the cause of the people, by the people, and for the people; mass mobilization work is the responsibility of the Party, State and mass organizations and the driving force to promote mass movement to meet the practical interests of the people and harmoniously combine citizens' 
interests, rights and obligations [11]. In the book "Mass mobilization of State Agencies in the New Period," Nguyen Tien Thinh said that the mobilization of state agencies should focus on implementing the policy of propagating and mobilizing the people to live and work under the Constitution [12]. The book "Applying Ho Chi Minh's thought to the mass mobilization work in the renovation era" provides many arguments about the mobilization work in departments, branches, and unions in localities. It shows that the improvement of mass mobilization of the State agencies at all levels will contribute to the successful implementation of the task of socio-economic development, maintaining national defense and security, and building a political system [13].

The concept of the government's mass mobilization has a very wide connotation. The government's mass mobilization is the mobilization field of the State to propagate and mobilize people to live and work under the Constitution and the law at all levels at the central to grassroots levels. The textbook on mass mobilization of Ho Chi Minh National Academy of Politics has mentioned grassroots government work. This textbook also specifies why the grassroots government must do mass mobilization; how local authorities do mass mobilization work and come up with some measures to strengthen the government's mass mobilization [14].

The views and guidelines of the Party and State have issued many policies, well-implemented government mass mobilization, aiming to take better care of people's lives, for the happiness of the people. In the thesis on mass mobilization work of the People's Committee of Tien Lang district, Hai Phong city today, Nguyen Thi Mai Phuong mentioned and clarified the theoretical issues about the mobilization work of the People's Committee of Tien Lang district - Hai Phong city. The author shows that in the construction and promulgation of regulations for district government, officials and civil servants contacting the people must have a sincere attitude, respect for the people, guide and help people; they must exemplarily abide by the undertakings and policies of the Party and the laws of the State [15]. Agreeing with this point of view, Nguyen Tien Thinh mentioned this issue in the study "mass mobilization of State agencies in the new period". However, he stated that to effectively carry out this work, it is necessary to ensure operating costs and facilities, to pay attention to resolving cadre policy of the mass mobilization bloc, the Fatherland Front, and mass organizations [12]. Sharing the same viewpoint of Nguyen Tien Thinh, Duong Van An mentioned this issue in the article "on Doi Moi and improving the efficiency of mobilization work in current conditions". However, this author states that in response to the requirements of the new situation, the mass mobilization work still reveals many limitations and shortcomings. Therefore, continuing to innovate and improve the effectiveness of the mobilization work is an urgent task, requiring committees and authorities to quickly come up with specific solutions. On that basis, he has given six solutions, in which it is necessary to continue to innovate, improve the capacity and effectiveness of the mass mobilization work, to invest more in the mobilization work (about people, resources, means,...) so that the mass mobilization work can go one step ahead to make the people understand, believe, and support [16]. Agreeing with six solutions of Duong Van An, in the article "Building a contingent of mobilizing cadres to meet the requirements of the new period", Dang Dinh Phu mentioned the issues of ensuring the operating costs, facilitating material facilities, paying attention to and settling the staff policy of the mass mobilization bloc, the fronts, and mass organizations. However, this author further emphasized that public employees carrying out mass mobilization work must have a sincere attitude, respect the people, guide and help people. They must be an exemplary person in observing the undertakings and policies of the Party and laws of the State [17].

It is essential to talk about the concept of government mass mobilization in districts. We not only mention perceptions but also the attitude and behavior of public officials working in the public sector towards the people, there are movements and changes along with the shift of society through different historical stages.

The author has found that the mobilization of the government in the districts of Ho Chi Minh City is all activities of organizations, cadres, and civil servants in the system of district governments to implement the Party's undertakings, resolutions, and directives, and the State's laws on mobilization work; propagate, mobilize and organize all people in the district, related organizations and forces to form a great force and power of the entire people to successfully implement the Party's guidelines, policies and laws of the State, first of all, is to successfully carry out the duties of the district government to ensure the successful implementation of the political tasks of the district, to promote ownership and improve the material life and spirit of the people in the district.

\section{Results and Discussion}

\subsection{Applying Public Mobilization Work in the Districts and Districts in Ho Chi Minh City in the Development of the City}

The mobilization of the government in the districts in Ho Chi Minh City now has contributed to the development of the city. In 2019, the economic growth rate is high, in terms of city size, it accounts for only $0.6 \%$ of the area and $8.3 \%$ of the population, but contributes $20.2 \%$ of the total national product, $26.1 \%$ of the price. industrial production value and $44 \%$ foreign investment projects. Over the past years, the Ho Chi Minh City Party Committee and government of Ho Chi Minh City have been deeply aware that, under the condition that the ruling party takes the lead in building socialism and firmly defending the Fatherland, especially in the current reform period. The Party has government from central to grassroots level - a powerful and sharp tool for the Party to successfully implement the renovation's objectives and tasks. 
Under the leadership of the Party, the government performs its main functions and tasks of state management overall activities taking place in society. To perform their functions and tasks well, the authorities at all levels cannot only by administrative orders but also have to use many other methods. One of the very important methods is that the government directly conducts the mobilization work. The government at all levels of the city, including the district governments, actively carried out the mobilization work to get initial results. The mobilization work of the authorities of the districts in Ho Chi Minh City has had positive changes: the organization, apparatus, and civil servants of the government from the city to the grassroots have been strengthened; the contents and modes of mobilization work of the district government have been reformed, initially bringing into play the role of the district government in directing and orienting revolutionary action movements of the people; the government has paid attention to and directed the work of religion and ethnic groups to achieve results. Through the mobilization work, several district governments have been quite successful in effectively resolving many outstanding and complex cases of land of religious origin, clearance for public services, socio-economic process, wellperforming the reconciliation to win the support of the people. District authorities in many places have shown quite clearly their role in implementing the Democracy Regulation at the grassroots level, gradually bringing this activity into order and bringing into play its positive effects. These changes have made an important contribution to changing the awareness of many government officials, including some leaders and managers, about the government's public affairs in current conditions, making an important contribution to focus on successful implementation of functions and duties of district authorities to improve the position and role of district governments in the renovation work in the district and Ho Chi Minh city.

\subsection{Problems Raised from the Practice of Districts in Ho Chi Minh City}

From the above theory and realities and the mandate of the district government, it shows that the problems raised about the public mobilization work in the districts of Ho Chi Minh City today focus on the following 07 issues:

First, to develop specific programs and plans to implement the Party's guidelines, resolutions and directives, and State laws on mobilization work in the district. Strictly implementing legal provisions on democratic implementation inwards, agencies, and grassroots units.

Second, implementing administrative procedure reform; publicity and transparency of guidelines and policies; socioeconomic development programs and projects in districts; revenues and expenditures from the budget and other sources; administrative procedures and the process of settling administrative procedures following the law.

Third, building and implementing a regime of direct contact and direct dialogue with the people and periodic reception; seriously absorb the people's comments and suggestions on the management, administration, attitude, and working style of cadres and civil servants of the district government agencies; promptly settle complaints, complaints, denunciations and pressing problems of the people in the district.

Fourth, regularly inspect the implementation of the Party's resolutions and directives on the work of mobilization. Coordinate with the mobilization committee of the district to direct and inspect the implementation of the laws on democracy at the grassroots level and the mobilization work of the government.

Fifth, coordinate with the Fatherland Front and the unions of the district to mobilize people to carry out economic, social, security, and national defense tasks. Organize consultation of the Fatherland Front, unions, and people to participate in building policies, plans, and major programs and projects of the district. Regularly listen and promptly resolve opinions of the Front and mass organizations to reflect and propose to the district authorities on issues that are of concern to the people. Periodically work with the Fatherland Front and the district people's unions.

Sixth, building and issuing regulations for district government officials and civil servants in performing public duties, in contacting and handling affairs with the people must have a sincere attitude, respect for the people, direction lead and help the people; she is an exemplary person in observing the undertakings and policies of the Party and laws of the State. Promptly and strictly handling cadres and civil servants of the district government agencies who have negative behaviors, harass, cause troubles to the people, infringe upon the legitimate and legitimate rights and interests of citizens in public service.

Finally, ensuring operating costs and facilitating facilities, paying attention to resolving cadres policy of the mass mobilization, Fatherland Front, and mass organizations.

\section{Conclusion}

The mass mobilization work of the government is an extremely large field of activity, scientific, and artistic. With the perspectives and theories of the previous authors, as well as with the theoretical and practical basis which has been studied quite carefully, the author has deeply explored the contribution of the civil mobilization work of the district authorities for the development of the city. At this point, it is necessary to review some of the following basic features:

From the perspectives and theories of the previous researchers, they also went into depth to explore these diverse and complex aspects. Research authors have come from many different perspectives to solve the research problem theoretically. The author believes that the civil mobilization of the district authorities is the activities of organizations, cadres, and civil servants in the district government system to implement the guidelines, resolutions, and directives of the Party. and the State's laws on mobilization work.

The author has shown the contribution of the mobilization 
of the district authorities to the development of the city as well as in the road to socialism in Vietnam. The author shows seven problems arising from practical activities on the civil mobilization work of districts in Ho Chi Minh City today.

\section{References}

[1] Marx, K. (1850). Class fight in France from 1848 to 1850, Journal Neue Rheinische Zeitung. Politisch-okonomische Revue Issue 1, 2, 3 and 5, 6.

[2] Ho Chi Minh (2000). Complete work. Vol. 2. Hanoi: National Political Publishing House, p. 677.

[3] Ho Chi Minh (2000). Complete work. Vol. 2. Hanoi: National Political Publishing House, pp. 267-268.

[4] "Communication for development". UNICEF

[5] Ho Chi Minh (2000). Complete Works. Vol. 5. Hanoi: National Political Publishing House 2000, p. 699.

[6] Party Central Executive Committee (Term VI), Resolution of the Eighth Conference on renewing the party's work, strengthening relations between the Party and the people, No: 08B-NQ / HNTW, March 27, 1990.

[7] Nguyen Van Linh (1986). Regarding the current mass mobilization. Hanoi: The Truth Publisher.

[8] Nguyen Van Linh (1987). Regarding mass mobilization. Hanoi: The Truth Publisher.
[9] Nguyen Van Linh (1991). Renewing the work of the masses. Hanoi: The truth Publisher.

[10] Huy Tho (2002), Anh Linh with grassroots. Hanoi: National Political Publishing House.

[11] Central Propaganda Department (2003). The Party's mobilization work during the period of accelerating national industrialization and modernization, Hanoi: National Political Publishing House.

[12] Nguyen Tien Thinh (2005). The mobilization work of state agencies in the new era. Hanoi: Judicial Publisher.

[13] Central Committee for Mobilization (2005). Applying Ho Chi Minh's thought to the work of mobilization in the new era. Hanoi: National Political Publishing House.

[14] Ho Chi Minh National Academy of Politics (2004). Intermediate textbook on political theory on civil mobilization work. Hanoi: Political theory publisher.

[15] Nguyen Thi Mai Phuong (2015). Postgraduate dissertation on the work of mobilization of the People's Committee of Tien Lang district, Hai Phong city today.

[16] Duong Van An (2019). Renovating and improving the effectiveness of the mobilization work in current conditions, the Communist Review, on December 10, 2019.

[17] Dang Dinh Phu (2011). Building a contingent of civil society officials to meet the requirements of the new era, Dan Van Magazine, Issue 9. 